Article

J. Mex. Chem. Soc. 2018, 62(1)

(C)2018, Sociedad Química de México

ISSN-e 2594-0317

ISSN 1870-249X

\title{
Use in vitro of Gold Nanoparticles Functionalized with Folic Acid as a Photothermal Agent on Treatment of HeLa Cells
}

\author{
Linda Bertel Garay ${ }^{* 1,2}$, Stelia Carolina Méndez Sánchez ${ }^{3,4}$, Fernando Martínez Ortega ${ }^{* 1,2}$ \\ ${ }^{1}$ Centro de Investigaciones en Catálisis, Universidad Industrial de Santander, Sede Guatiguará UIS Km 2 vía Refugio, \\ Piedecuesta, Colombia. \\ ${ }^{2}$ Centro de Investigación científica y Tecnológica en Materiales y Nanociencias (CMN), Universidad Industrial de \\ Santander, Sede Guatiguará UIS Km 2 vía Refugio, Piedecuesta, Colombia. \\ ${ }^{3}$ Grupo de Investigación en Bioquímica y Microbiología GIBIM, Universidad Industrial de Santander, Sede Guatiguará \\ UIS Km 2 vía Refugio, Piedecuesta, Colombia. \\ ${ }^{4}$ Agrobiotech Research Center ABC, Universidad Industrial de Santander, Sede Guatiguará UIS Km 2 vía Refugio, \\ Piedecuesta, Colombia. \\ *Corresponding autor: Linda Bertel Garay, linda.bertel@correo.uis.edu.co, Tel: (+57)3015173122
}

Fernando Martínez Ortega, fmartine@uis.edu.co,Tel: (+57)3164680145

Stelia Carolina Méndez Sánchez, scmendez@uis.edu.co, Tel:(+57) 3176468029

Received November 16 ${ }^{\text {th }}$, 2017; Accepted February 12 2018.

DOI: http://dx.doi.org/10.29356/jmcs.v62i1.385

\begin{abstract}
Folic acid (FA) is used as a recognition molecule to achieve selective internalization in cancer cells. Here functionalized gold nanoparticles with folic acid (AuNP-FA) are proposed as suitable therapeutic agents for cervix cancer cells by photothermal damage. The functionalized gold nanoparticles with folic acid were synthesized by mixing hydrogen tetrachloroaurate with folic acid in a molar ratio of $0.56 / 1$ under radiation of mercury lamp $\left(\lambda_{\max }=254 \mathrm{~nm}\right)$. HeLa cells were incubated with AuNP-FA during $48 \mathrm{~h}$, then were irradiated and the cytotoxicity was analyzed $12 \mathrm{~h}$ after irradiation. The AuNP-FA were dose-dependent cytotoxic under irradiation and not cytotoxic in the absence of radiation. The viability of cancer cells treated with functionalized and non-functionalized gold nanoparticles (AuNPs), with and without near infrared light at $808 \mathrm{~nm}$, was measured by MTT assays. This work provides useful guidance toward the synthesis of biocompatible nanomaterials for biological applications.
\end{abstract}

Key words: Folic acid; gold nanoparticles; near infrared; photothermal effect; cancer cells; plasmonic photothermal therapy.

Resumen. El ácido fólico es utilizado como molécula de reconocimiento para lograr una internalización selectiva en las células cancerosas. Aquí nanopartículas de oro funcionalizadas con ácido fólico son propuestas como agentes terapéuticos para células de cáncer de cérvix a través de daño fototérmico. Las nanopartículas funcionalizadas con ácido fólico fueron sintetizadas al mezclar tetracloroaurato de hidrógeno con ácido fólico en una relación molar de 0.56/1 bajo la radiación de una lámpara de mercurio $\left(\lambda_{\operatorname{máx}}=254 \mathrm{~nm}\right)$. Las células HeLa fueron incubadas con las nanopartículas funcionalizadas durante 48 horas, luego fueron irradiadas y 12 horas después se analizó la citotoxicidad. Las nanopartículas funcionalizadas fueron citotóxicas de manera dosis-dependiente y no citotóxicas en ausencia de radiación. La viabilidad de las células cancerosas tratadas con nanopartículas de oro funcionalizadas y no funcionalizadas, con y sin luz infrarroja cercana a 808 nm, se midió mediante ensayos de MTT. Este trabajo proporciona una guía útil para la síntesis de nanomateriales biocompatibles para aplicaciones biológicas.

Palabras claves: ácido fólico; nanopartículas de oro; infrarrojo cercano; efecto fototérmico; células cancerosas; terapia fototérmica plasmónica. 
Article

J. Mex. Chem. Soc. 2018, 62(1)

(C2018, Sociedad Química de México

ISSN-e 2594-0317

ISSN 1870-249X

\section{Introduction}

Gold nanoparticles (AuNPs) have been subject of research due to their unique property of surface plasmon absorption (SPA). SPA occurs from resonant oscillation of their free electrons at a particular wavelength of the light. This process allows converting light to heat and AuNPs were used to produce a photothermal effect into the cancer cells [1-3]. However, AuNPs functionalized with special biomolecules is required in order to facilitate their cell internalization. FA [48] or Anti-epidermal growth factor receptor of monoclonal antibodies (anti-EGFR) [6] have been proposed to allow specific recognition or internalization by cancer cells. In this sense, Li et al. [4] have obtained AuNPs functionalized with FA through one-step synthesis and were incubated in HeLa cells where the intracellular uptake of these conjugates was facilitated by overexpressing folate receptor of the cells.

AuNPs have been synthesized by several methods, including chemical and photochemical procedures. Chemical methods mainly involve reduction of chloroauric acid by a specific reducer. Spherical AuNPs are prepared by reduction of chloroauric acid with sodium citrate in doubly distilled water. The size of AuNPs is controlled using the different concentrations of sodium citrate [9]. Gold nanorods (AuNRs) are prepared from $\mathrm{HAuCl}_{4}$ with CTAB (hexadecyltrimethylammonium bromide) as template $[10,11]$. The triangular or hexagonal shapes of AuNPs are generated by a photochemical methods, but this procedure requires an illumination with ultraviolet radiation (mercury lamp $\lambda_{\max }=306$ $\mathrm{nm}$ ) to carry out the reduction of $\mathrm{HAuCl}_{4}$ in presence of sodium oxalate [12]. Eustis et al. [13] have proposed the synthesis of AuNPs using $\mathrm{HAuCl}_{4}$ with ethylene glycol and poly(vinylpyrrolidone) under radiation (250-400 nm).

FA $[4,14]$ and FA-linked drugs are recognized with high affinity $\left(K_{d} c 100 p M\right)$ by folate receptor [15]. The receptor of FA represents a useful target for selective delivery into cancer cells, because folate receptors are particularly overexpressed in many cancers like cancers of the breast, ovaries, endometrium, kidneys, colon, brain, and myeloid cells of hematopoietic origin but present an expression restricted on normal tissues [15, 16].

AuNP functionalized with FA have been used in plasmonic photothermal therapy (PPTT) with promising results as an independent strategy for highly selective cancer treatment. Tong et al. [17] have synthesized and functionalized AuNRs with FA and were incubated with KB carcinoma cells with high folate receptor expression and NIH-3T3 cells with low folate receptor expression. The KB cells incubated with FA-conjugated nanorods were exposed to continuous near infrared (NIR) laser at 6-60 $\mathrm{mW}$ and showed photoinduced injury and not injuries were observed in NIH-3T3 cells. Recently, Volsi et al. [18] combined PPTT and Chemotherapy for osteosarcoma treatment, using folate-targeted gold nanorods, an amphiphilic polysaccharide based graft-copolymer (INU-LA-PEG-FA) and an amino derivative of the $\alpha, \beta-p o l y(N-2-$ hydroxyethyl)-d,l-aspartamide functionalized with folic acid (PHEA-EDA-FA). This nanosystem controlled drug release and caused hyperthermia efficiently.

Recent works have functionalized gold nanoparticles with FA using linkers (4-aminothiophenol, 6-mercapto-1hexanol) [19] or incorporating other molecules (N-hydroxysuccinimide terminated oligonucleotide, NH2-terminated PEGfolic acid) [20]. These nanoconjugates were used in the PPTT of cancer cells, obtaining favorable results.

This work demonstrates that a photochemical method can be used to synthesize AF-functionalized AuNPs on onestep and then be used in the PPTT of HeLa cells achieving the decrease in cell viability in a statistically significant way. In addition, the synthesized nanoconjugate is a simple system that does not contain linkers or other molecules that could complicate the action mechanism of the nanoparticle or affect its biocompatibility.

\section{Experimental}

\section{Synthesis of gold nanoparticles functionalized with FA.}

Nanoconjugated system was prepared according to the method reported by Castillo et al. [21] with some modifications. Briefly, $330 \mu \mathrm{L}$ of $5 \mathrm{mM}$ FA (Merck) were added to $9.37 \mathrm{~mL}$ of MilliQ water with shaking in a photochemical reactor (Ace-Glass model T-121m), which was wrapped with aluminum foil. And then $300 \mu \mathrm{L}$ of $0.01 \mathrm{M}$ $\mathrm{HAuCl}_{4} .3 \mathrm{H}_{2} \mathrm{O}$ (Sigma) were added to reaction system and irradiated under a UV lamp $\left(\lambda_{\max }=254 \mathrm{~nm}\right)$ for 10 min at $19{ }^{\circ} \mathrm{C}$ using a thermostat bath. The $\mathrm{pH}$ of reaction mixture was fixed at $\mathrm{pH}=10.41$ using some drops of $\mathrm{NaOH} 0.1 \mathrm{M}$. The colloidal suspension of AuNP-FA was dialyzed during $8 \mathrm{~h}$ to remove excess free FA. The decrease in the amount of free FA was determined by a calibration curve for the range of concentrations between 0.01 and $0.25 \mathrm{mM}$, with a wavelength of maximum absorbance of $364 \mathrm{~nm}$. Dialysis was performed under sterile conditions in a laminar flow cabinet.

Non- functionalized gold nanoparticles were prepared, a mixture of $\mathrm{HAuCl}_{4} .3 \mathrm{H}_{2} \mathrm{O}(300 \mu \mathrm{L} ; 0.01 \mathrm{M})$ and $9.7 \mathrm{~mL}$ of MilliQ water was radiated by the UV lamp with magnetic agitation during 45 min, AuNPs. 
Article

J. Mex. Chem. Soc. 2018, 62(1)

(C)2018, Sociedad Química de México

ISSN-e 2594-0317

ISSN 1870-249X

\section{Characterizations of AuNP-FA.}

UV-Vis absorbance spectra were recorded using a Shimadzu UV-2401PC spectrophotometer with double-beam, the SPA band was characterized for all the nanoparticles prepared. Free FA and AuNP-FA solutions were analyzed by fluorescence spectroscopy with a Perkin Elmer LS-55 spectrofluorimeter. A drop of free FA or AuNP-FA solution was deposited on the diamond sample holder of a Nicolet FT-IR IS50 and air dried for ATR-IR measurements. SEM images and Energy Dispersive X-rays Spectroscopy (EDS) elemental analysis of AuNP-FA were obtained using a Quanta 650 FEG scanning electron microscope. Measurements of z-potential and particle size were performed on a Zetasizer Nano ZS90 equipment, for each solution of AuNPs and AuNP-FA prepared.

\section{Assays in HeLa cells.}

Human adenocarcinoma HeLa cells were selected in this work due to these cells overexpress folate receptor. HeLa cells in Eagle's Minimun Essential Medium (EMEM) supplemented with 10 \% FBS were added in 96 well plate (density of 5000 cells/well) and incubated for $24 \mathrm{~h}$ at $37^{\circ} \mathrm{C}$ with $5 \% \mathrm{CO}_{2}$ atmosphere. We studied the effect of AuNP and AuNP-FA

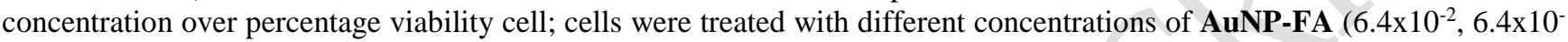
${ }^{1}$, 3.2 and $6.4 \mu \mathrm{g}$ de $\mathrm{Au} / \mathrm{mL}$ ) in EMEM. Meanwhile, a group of cells was treated with AuNP solutions at $6.4 \mu \mathrm{g} \mathrm{de} \mathrm{Au/mL}$ for comparison. Nanoparticles were not added to the control cells. After $48 \mathrm{~h}$ of treatment, cells were illuminated with a diode laser (ThorLabs Newton USA, $808 \mathrm{~nm}$ ) for $5 \mathrm{~min}$ at $800 \mathrm{~mW}$ of power. The irradiation effect was studied, and control cells were exposed to light (irradiated control). The distance between the diode and samples was about $2.5 \mathrm{~cm}$.

MTT assay was performed $12 \mathrm{~h}$ after irradiation. Simultaneously, treated cells and control cells were grown without irradiation in a different plate. Finally, the medium was discarded and $200 \mu \mathrm{L}$ of MTT $(500 \mu \mathrm{g} / \mathrm{mL}$ in HBSS) were added to each well. After $3 \mathrm{~h}$ of incubation, the supernatant was removed and $200 \mu \mathrm{L}$ of DMSO was added to dissolve the crystals formed. Absorbance was measured at $550 \mathrm{~nm}$ using a microplate reader, using DMSO as a blank [22].

Data were presented as means $\pm \mathrm{SE}$ from at least two independent experiments and compared by analysis of variance one way (ANOVA) followed by multiple comparison analysis averages, Tukey. Differences at $p<0.05$ were considered statistically significant.

\section{Results and discussion}

The AuNP-FA assayed had an amount of free FA removed through a dialysis process. The difference between the AF concentration in the colloidal suspension before and after the dialysis was $\sim 0.02 \mathrm{mM}$. The AuNPs solution shows a SPA band at $546 \mathrm{~nm}$ and some irregular shapes was observed, the hydrodynamic average size and Z potential were 112,1 11,4 $\mathrm{nm}$ and $0 \pm 0.19 \mathrm{mV}$ respectively.

Fig. 1 shows the UV-Vis absorption spectrum of AuNP-FA (in dashed line). The SPA band around at $537 \mathrm{~nm}$ indicates the formation of gold nanoparticles under photochemical reduction, and no band is observed in the spectra of the mixture solution before UV irradiation (in dotted line). The wide absorption peak is resulted from irregular sizes and shape of nanoparticles [23, 24], such as it is observed in SEM image of AuNP-FA, shape and size of nanoparticles are varied with some elongated bar-like, polygon or irregular, see Fig. 2. The hydrodynamic average size of AuNP-FA (Fig. 3) was $75.28 \pm 0.32 \mathrm{~nm}$. These solutions are adequate for PPTT in cancer cells, because they contain particles within nanometric range (1-100 nm). The average $\mathrm{Z}$ potential was $0.3 \pm 0.7 \mathrm{mV}$ indicating the charge density is low at the surface of AuNP-FA. 
Article

J. Mex. Chem. Soc. 2018, 62(1) (C)2018, Sociedad Química de México

ISSN-e 2594-0317

ISSN 1870-249X

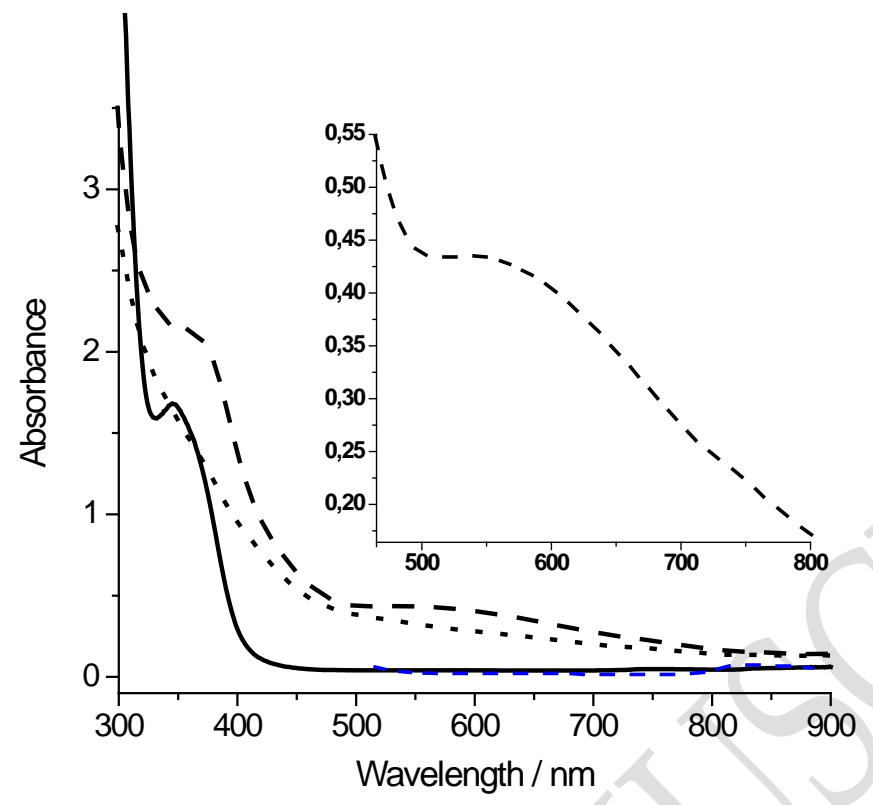

Figure 1. UV-Vis absorption spectrum of the free FA (solid line), reaction mixture before UV radiation (dotted line) and AuNP-FA (dashed line). Their inset is the spectrum of AuNP-FA amplified at SPA band region.

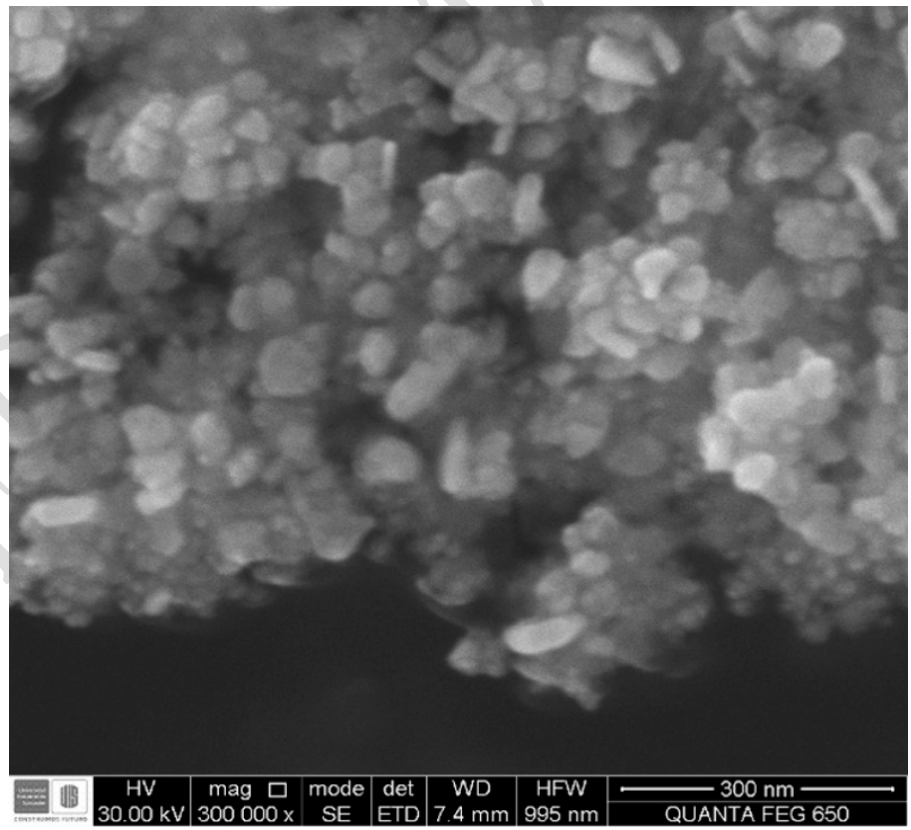

Figure 2. SEM image of the AuNP-FA. 


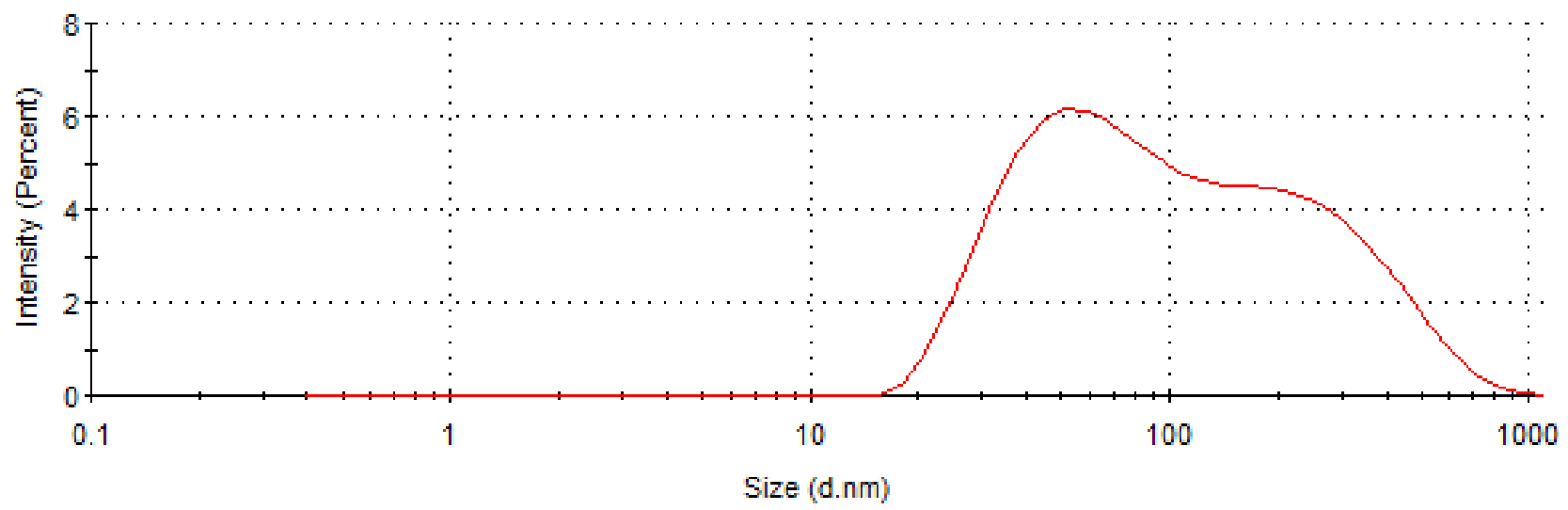

Figure 3. Size Distribution by Intensity of AuNP-FA

IEDS analysis shows the characteristic bands of Au (see Fig. 4), which forms the core of AuNP-FA. Furthermore, the presence of the elements $\mathrm{C}, \mathrm{N}$ and $\mathrm{O}$ belonging to the FA molecule could be detected and could indicate that functionalization of AuNPs with FA was done. However, notice that a portion of $\mathrm{C}$ can be detected because the carbon ribbon was used as a support. The signals that correspond to $\mathrm{Cu}$ may be due to the copper present in the sample holder.

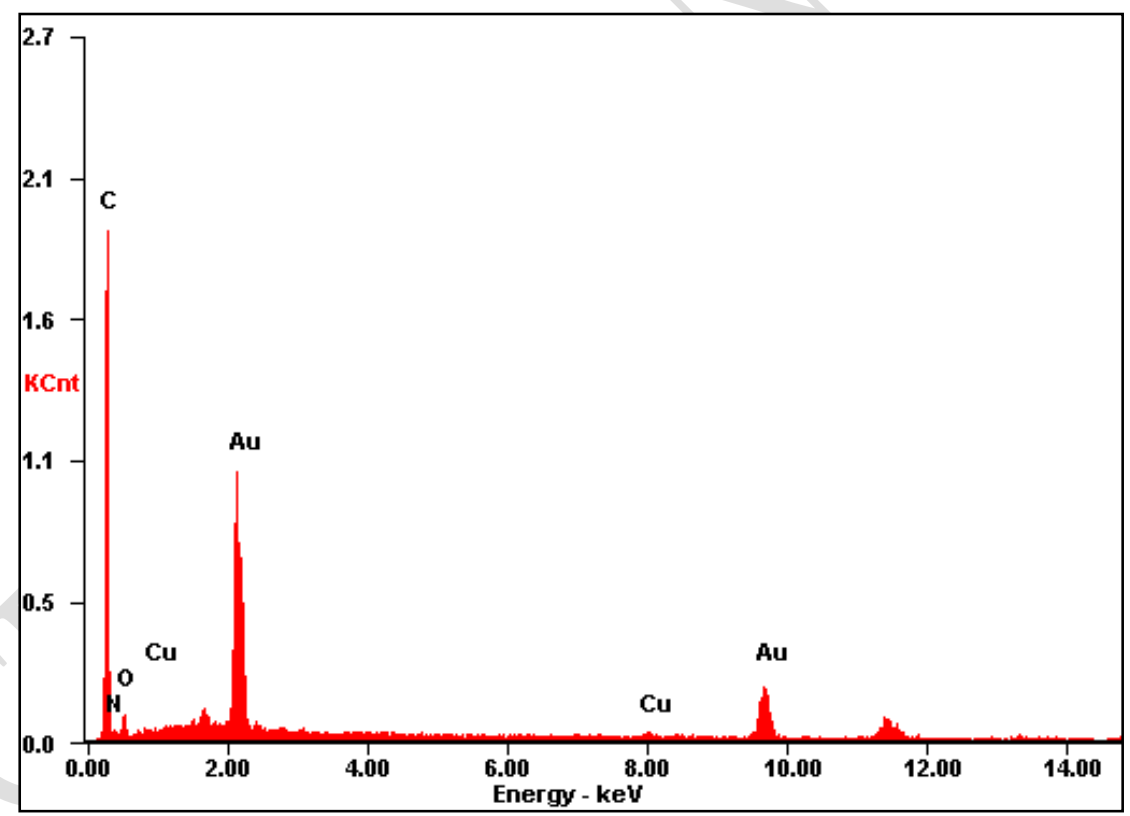

Figure 4. EDS spectra of AuNP-FA.

ATR-FTIR spectrum of free FA and AuNP-FA solutions (Fig. 5) were obtained in order to study the interaction between the FA with the surface of AuNP. Vibrations of pterin portion of free FA at $1680(\mathrm{C}=\mathrm{O}$ stretching $)$ and $1600 \mathrm{~cm}^{-1}$ (CN stretching of the $-\mathrm{C}\left(\mathrm{NH}_{2}\right)$-) experienced a shift to 1726 and $1646 \mathrm{~cm}^{-1}$ respectively, in the spectrum of AuNP-FA. Additionally, the absence of the peak due to skeletal vibration of the pterin ring at $1508 \mathrm{~cm}^{-1}$ could indicate that AuNPs perhaps interact strongly with pterin portion of FA. The peak at $1405 \mathrm{~cm}^{-1}$ (vibration of the carboxylate groups of the glutamate portion of FA) shifted to $1373 \mathrm{~cm}^{-1}$ in the AuNP-AF sample. That is to say, FA can interact with the surface of the AuNP-FA through the carboxylate groups of glutamic acid portion and amine group of pterin moiety. 


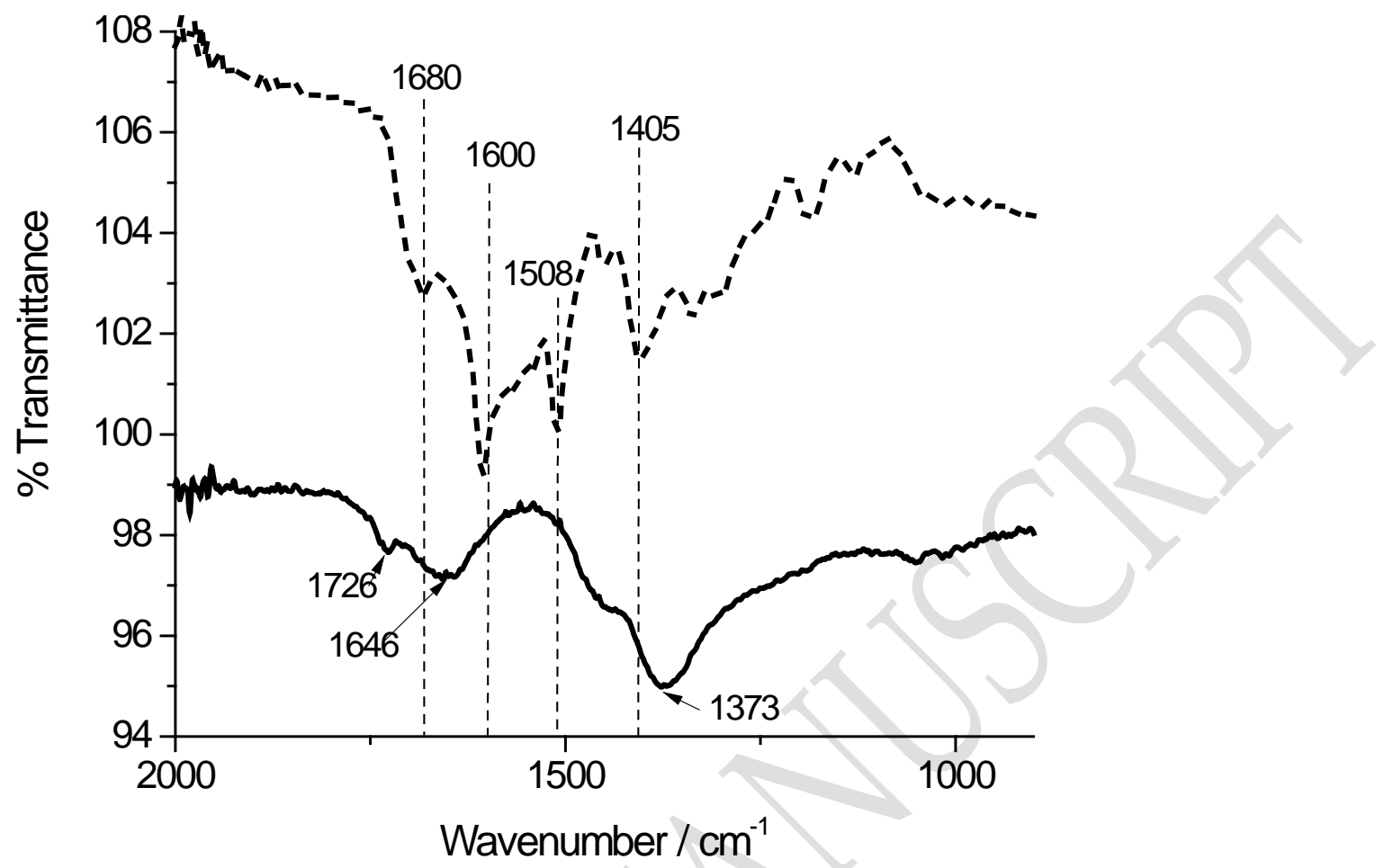

Figure 5. ATR-FTIR spectra of the free FA (dotted line) and AuNP-FA (solid line).

Castillo et al. [25] demonstrated that the FA interacts with gold-capped silicon nanopillars mainly through the nitrogen in the pterin moiety, when deposited a FA solution on gold-capped silicon nanopillars and did SERS and Raman analysis and DFT calculations. However, the z-potential near zero of the AuNP-FA could be related to the fact that the FA molecules are joined mainly by the carboxylic groups to the metal surface of the Au, leaving out the pterin ring (which at basic $\mathrm{pH}$ it has no charge). In accordance with this last, Chen et al. [26] observed that folate requires binding to the folate receptor through its pterin group and indicated that glutamate group is available for conjugation with drugs and imaging reagents, without impeding the correct interaction between receptor and folate.

Fluorescence spectroscopy analysis was used to demonstrate the interaction of FA with AuNPs. Fig. 6 shows that the fluorescence emission of FA is efficiency improved by presence of AuNP, where the increase in fluorescence emission of fluorophores is attributed to an amplified electric field close to the metal surface induced by the incident light [27, 28]. 
Article

J. Mex. Chem. Soc. 2018, 62(1)

(C)2018, Sociedad Química de México

ISSN-e 2594-0317

ISSN 1870-249X

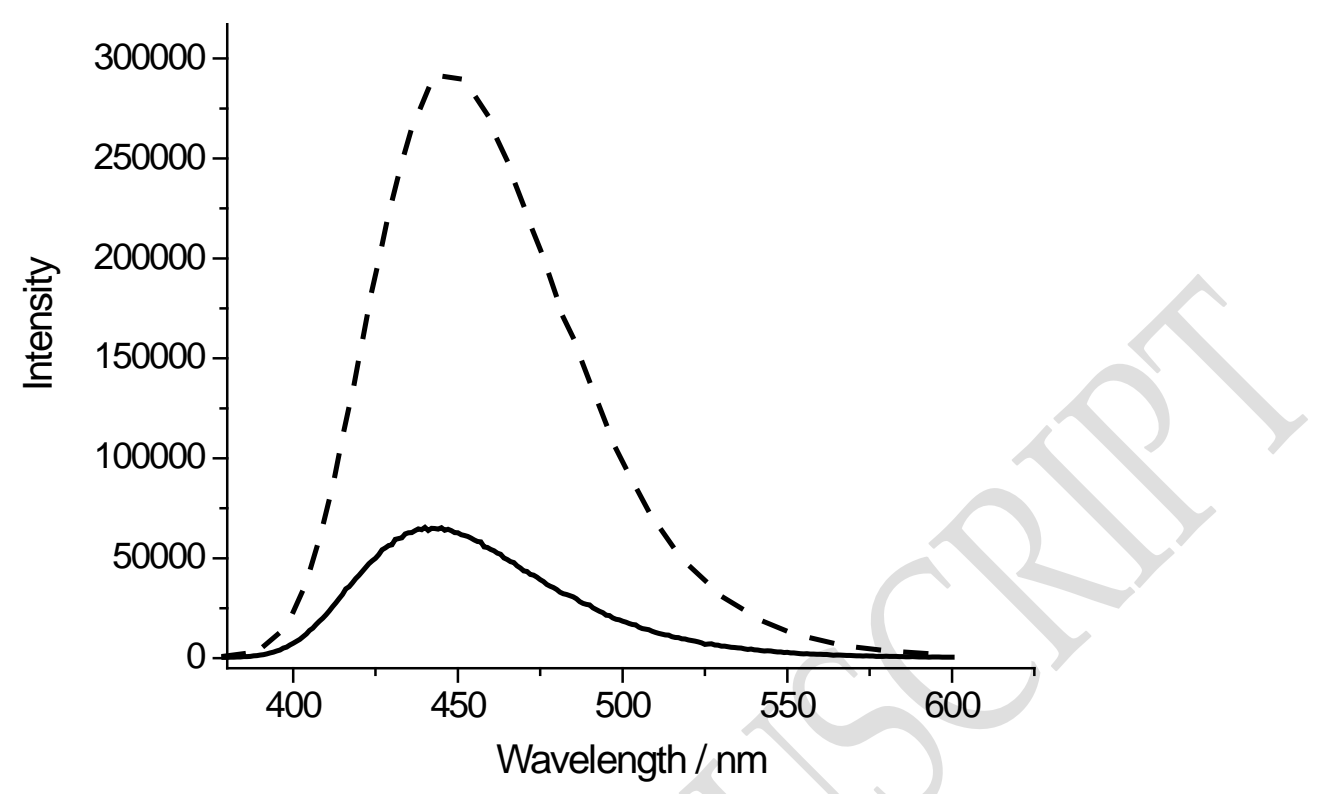

Figure 6. Fluorescence emission spectra of free FA (solid line) and AuNP-FA (dashed line).

In this study, HeLa cells were used as target cells which present the folate receptor in membrane surface. The cells were treated with AuNP-FA and AuNPs to verify that FA is responsible for the internalization of AuNPs. The cell viability was determined as the percentage of the viable cells against control group cells. HeLa cells treated with AuNP-FA without irradiation do not showed statistically significant difference in cytotoxicity with any concentration tested in comparison to cells control (see Fig. 7, without irradiation). Though, after 5 min of NIR irradiation, the AuNP-FA internalized affects cell viability in a dose dependent manner. In consequence of interaction between nanoparticles and NIR radiation generated a decrease of cell viability at higher concentrations of AuNP-FA (3.2 and $6.4 \mu \mathrm{g} / \mathrm{mL}$ ). The morphology of HeLa cells treated with AuNP-AF with the two highest AuNP-FA concentrations were dramatically altered while for the two lower concentrations of AuNP-FA the cell morphology is not altered, see Fig. 8. 
Article

J. Mex. Chem. Soc. 2018, 62(1)

(C)2018, Sociedad Química de México

ISSN-e 2594-0317

ISSN 1870-249X

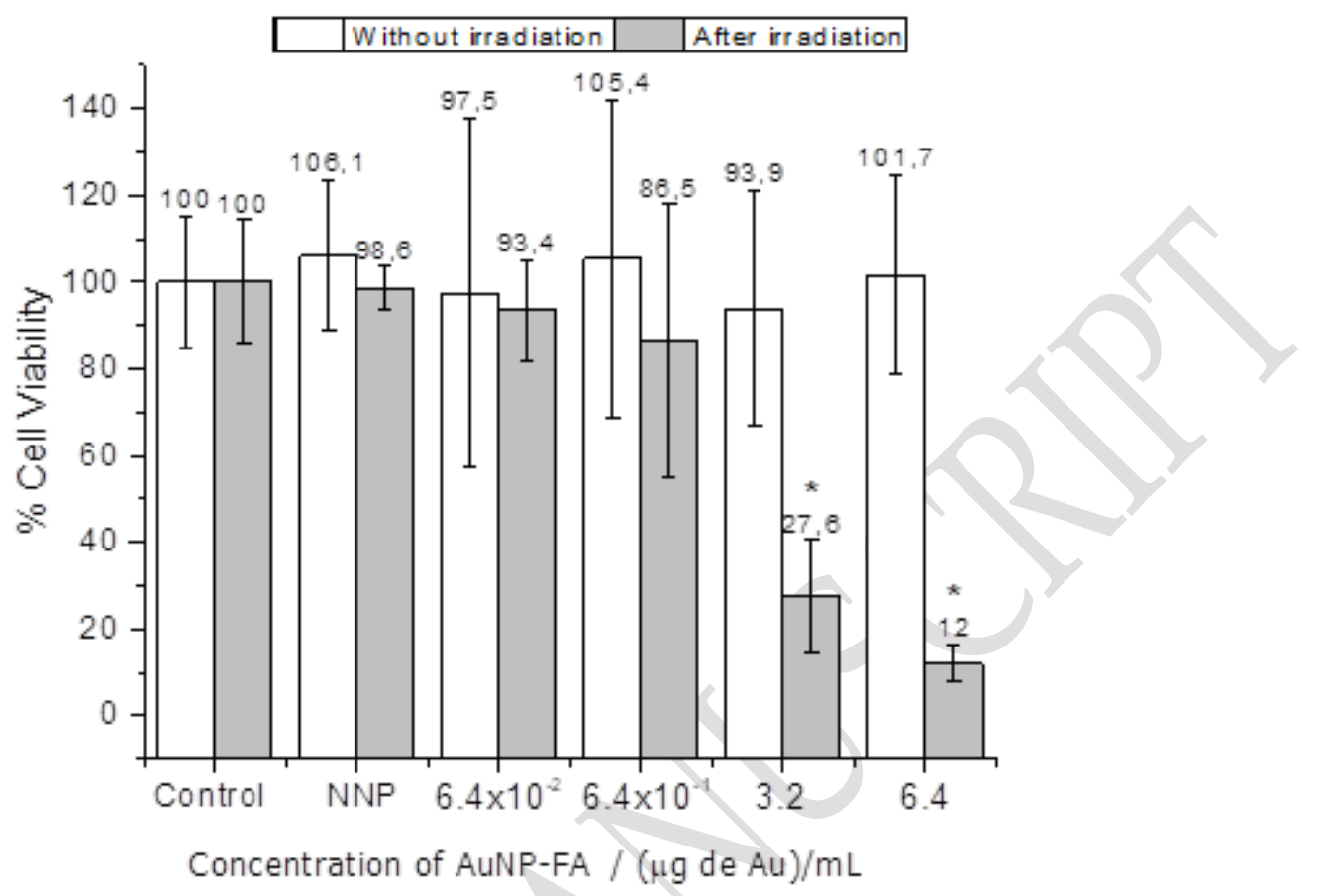

Figure 7. Effect of FA-AuNP on the viability of HeLa cells with and without irradiation NIR. Control: cells not treated with nanoparticles. NNP: cells treated with naked AuNPs. Cells were treated for $74 \mathrm{~h}$. * Statistically significant difference compared to non-irradiated cells and treated with the same concentration of nanoparticles, $p<0.05$.

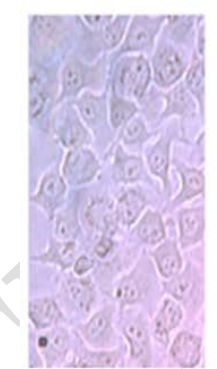

Unirradiated Control

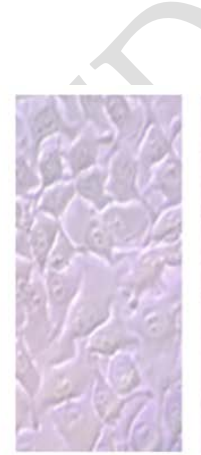

Irradiated Control

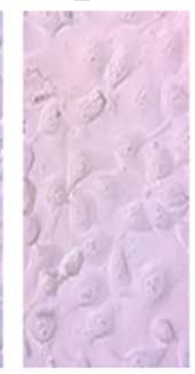

$6,4 \times 10^{-2}$ $\mu \mathrm{g} / \mathrm{mL}$

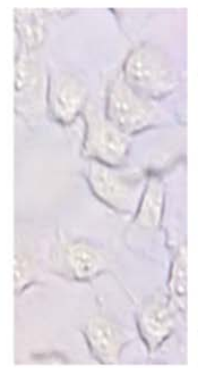

$6,4 \times 10^{-1}$ $\mu \mathrm{g} / \mathrm{mL}$

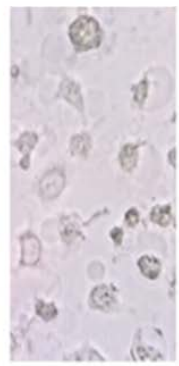

$3,2 \mu \mathrm{g} / \mathrm{mL}$

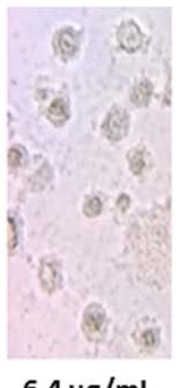

$6,4 \mu \mathrm{g} / \mathrm{mL}$

Figure 8. HeLa cells treated with AuNP-AF after NIR irradiation for 5 min by optical microscope views 40X.

In the case of HeLa cells treated with AuNPs with and without irradiation, cytotoxic effects were not observed although, previously, we observed that AuNPs solutions exhibited photo-thermal response when exposed to NIR radiation (diode laser $808 \mathrm{~nm}$ ). This result suggests that uptake of AuNPs was low and when they were irradiated not generate a photo-thermal effect. Chithrani et al. [29] founded that the internalization of naked AuNP into HeLa cells is minimal and independently of particle size. Therefore, we suspect cell thermal damage can be promoted once sufficient nanoparticles have entered the cell. 


\section{Conclusion}

In this work the AuNPs functionalized with FA were prepared by a photochemical methodology with a SPA band wide in the visible light region. This preparation of AuNP-FA has an important advantage, because it is free of reagents (surfactants and polymers) typically used as template and stabilizing agents during synthesis of AuNPs. When HeLa cells are treated with AuNP-FA and exposed to NIR radiation, we observed changes in cell viability by photothermal damage in function of concentration of AuNP-FA. The irradiation time (5 min) and power of light (800 $\mathrm{mW}$ ) applied were low, so that NIR radiation was innocuous for cells untreated. This fact has a potential advantage for applications future of photothermal therapy for cancer.

\section{Acknowledgements}

This work was supported by the Universidad Industrial de Santander (project DIEF 1782). The authors would like to acknowledge teams of Laboratorio de Microscopia by SEM images and Laboratorio de espectrocopia by ATR-FTIR spectra of Parque Tecnológico de Guatiguará.

\section{References}

1. Huang, X.; El-Sayed, I. H.; Qian, W.; El-Sayed, M. A. J. Am. Chem. Soc. 2006, 28, 2115-2120.

2. Huang, X.; Qian, W.; El-Sayed, I. H.; El-Sayed, M. A. Lasers Surg. Med. 2007, 39, 747-753.

3. Abdulla-Al-Mamun, M.; Kusumoto, Y.; Mihata, A.; Islam, M. S.; Ahmmad, B. Photochem. Photobiol. Sci. 2009, 8, $1125-1129$.

4. Li, G.; Li, D.; Zhang, L.; Zhai, J.; Wang, E. Chem. Eur. J. 2009, 15, 9868-9873.

5. Zhang, Z.; Jia, J.; Lai, Y.; Ma, Y.; Weng, J.; Sun, L. Bioorg. Med. Chem. 2010, 18, 5528-5534.

6. Tsai, S.-W.; Liaw, J.-W.; Hsu, F.-Y.; Chen, Y.-Y.; Lyu, M.-J.; Yeh, M.-H. Sensors. 2008, 8, 6660-6673.

7. Devendiran, R. M.; Chinnaiyan, S.K.; Yadavb, N.K.; Moorthy, G.K.; Ramanathan, G.; Singaravelu, S.; Sivagnanam, U.T.; Perumal, P.T. RSC Adv. 2016, 6, 29757-29768.

8. Rogert, E.; Kalscheuer, S.; Kirtane, A.; Raja, B.; Grill, A. E.; Whittum-Hudson, J.; Panyam, J. Mol. Pharmaceutics. 2012, 9, 2103-2110.

9. He, Y. Q.; Liu, S. P.; Kong, L.; Liu, Z. F. Spectrochimica Acta Part A. 2005, 61, 2861-2866.

10. Nikoobakht, B.; El-sayed, M. A. Chem. Mater. 2003, 15, 1957-1962.

11. Jana, N. R.: Gearheart, L.; Murphy, C. J. J. Phys. Chem. B. 2001, 105, 4065-4067.

12. Huang, W.-C.; Chen, Y.-C. J. Nanoparticle Res. 2008, 10, 697-702.

13. Eustis, S.; Hsu, H.; El-sayed, M. A. J. Phys. Chem. B. 2005, 109, 4811-4815.

14. Jhaveri, M. S.; Wagner, C.; Trepel, J. B. Mol. Pharmacol. 2001, 60, 1288-1295.

15. Sega, E. I.; Low, P. S. Cancer Metastasis Rev. 2008, 27, 655-664.

16. Zhang, Z.; Jia, J.; Lai, Y.; Ma, Y.; Weng, J.; Sun, L. Bioorg. Med. Chem. 2010, 18, 5528-5534.

17. Tong, L.; Zhao, Y.; Huff, T. B; Hansen, M. N; Wei, A.; Cheng, J.-X. Adv. Mater. 2007, 19, 3136-3141.

18. Volsi, A. L.; Scialabba, C.; Vetri, V.; Cavallaro, G.; Licciardi, M.; Giammona, G. ACS Appl. Mater. Interfaces. 2017, 9, 14453-14469.

19. Mansoori, G. A.; Brandenburg, K. S.; Shakeri-Zadeh, A. Cancers. 2010, 2, 1911-1928.

20. Xiao, Z.; Ji, C.; Shi, J.; Pridgen, E. M.; Frieder, J, Wu, J.; Farokhzad, O. C. Angew. Chem. 2012, 124, 12023-12027.

21. Castillo, J.; Bertel, L.; Páez-Mozo, E.; Martínez, F. Nanomater. nanotechnol. 2013, 3, 1-6.

22. Mosmann, T. J. Immunol. Methods. 1983, 65, 55-63.

23. Sapsford, K. E.; Algar, W. R.; Berti, L.; Gemmill, K. B.; Casey, B. J.; Oh, E.; Stewart, M. H.; Medintz, I. L. Chem. Rev. 2013, 113, 1904-2074.

24. Hu, J.; Wang, Z.; Li, J. Sensors. 2007, 7, 3299-3311.

25. Castillo, J. J.; Rindzevicius, T.; Rozo, C. E.; Boisen, A. Nanomater. Nanotechnol. 2015, 5, 1-7.

26. Chen, C.; Ke, J.; Zhou, X. E.; Yi, W.; Brunzelle, J. S.; Li, J.; Yong, E.-L.; Xu, H. E.; Melcher, K. Nature. 2013, 500, 486-489.

27. Horimoto, N. N.; Imura, K.; Okamoto, H. Chem. Phys. Lett. 2008, 467, 105-109.

28. Chhabra, R.; Sharma, J.; Wang, H.; Zou, S.; Lin, S.; Yan, H.; Lindsay, S.; Liu, Y. Nanotechnology. 2009, 20, 1-10.

29. Chithrani, B. D.; Chan, W. C. W. Nano Lett. 2007, 7, 1542-1550. 